\title{
AKUISISI BAHAN PUSTAKA PERPUSTAKAAN JURUSAN PENDIDIKAN BAHASA INGGRIS FAKULTAS TARBIYAH DAN KEGURUAN UNIVERSITAS ISLAM NEGERI ANTASARI BANJARMASIN
}

\author{
Sari Wahdati ${ }^{1}$ \\ ${ }^{1}$ Mahasiswa Ilmu Perpustakaan Dan Informasi \\ Universitas Islam Negeri Sunan KalijagaYogyakarta \\ sariwahdati@gmail.com
}

\begin{abstract}
ABSTRAK
Penelitian ini berjudul akuisisi bahan pustaka perpustakaan jurusan pendidikan bahasa inggris fakultas tarbiyah dan keguruan universitas islam negeri antasari banjarmasin. Tujuan dari penelitian ini adalah untuk mengetahui bagaimana sistem pengadaan bahan pustaka di perpustakaan jurusan pendidikan bahasa inggris fakultas tarbiyah dan keguruan universitas islam negeri antasari banjarmasin. Sampel dari penelitian ini adalah pustakawan di jurusan pendidikan bahasa inggris fakultas tarbiyah dan keguruan universitas islam negeri antasari banjarmasin. Metode penilitan menggunakan metode kualitatif, teknik pengumpulan data yang digunakan adalah observasi, wawancara dan dokumentasi. Hasil dari penelitian ini menunjukan bahwa perpustakaan memerlukan staf tambahan yang sesuai dengan ahli ilmu perpustakaan, dana yang di dapat untuk pengadaan bahan pustaka tidak menentu di setiap bulan bahkan tahun, perpustakaan belum mempuynyai SOP dalam pengadaan bahan pustaka secara tertulis. Prosedur pemilihan bahan pustaka di tentukan oleh dosen, staf, pustakawan dan mahasiswa. Sistem pengadaan bahan pustaka melalui pembelian, hadiah dan sumbangan.
\end{abstract}

Kata Kunci : Pengadaan, Bahan Pustaka, Perpustakaan

\section{ABSTRACT}

This research entitled Library Acquisition of English Department Major of the Tarbiyah Faculty Islamic State University of Antasari Banjarmasin. The purpose of this study is to know how is the acquisition library system at English Department Major of the Tarbiyah Faculty Islamic State University of Antasari Banjarmasin. The sample from this study is librarian English Department Major of the Tarbiyah Faculty Islamic State University of Antasari Banjarmasin. The methodology research using a qualitative method. Data collection technique used observation, interview, and documentation. The findings of this research show that the library needs more staff under the field of library experts, the budget for acquisition not stabilized in every month or year, the library has not a standard operating procedure in library acquisition written. The acquisition includes the selection of library materials conducted by lecturers, staffs, librarians, and students. The library acquisition system is implemented through purchases, gifts or grants and contribution.

Keywords: Acquisition, Library Materials, Library 


\section{PENDAHULUAN}

Perpustakaan adalah tempat dimana sumber informasi dan ilmu pengetahuan dapat di peroleh oleh siapapun, informasi tersebut bisa dalam bentuk buku atau karya cetak maupun elektronik. Menurut Basuki, perpustakaan adalah sebuah ruangan, bagian sebuah gedung, ataupun gedung itu sendiri yang di gunakan untuk menyimpan buku dan terbitan lainnya yang biasanya disimpan menurut data susunan tertentu untuk digunakan pembaca, bukan untuk dijual (Sulistiyo Basuki, 1991:3).

Perpustakaan di bagi menjadi lima jenis yaitu perpustakaan nasional, perpustakaan umum, perpustakaan perguruan tinggi, perpustakaan sekolah dan perpustakaan khusus. Pada dasarnya fungsi dari semua perpustakaan tersebut sama adalah sebagai sumber informasi bagi masyarakat. Salah satu jenis perpustakaan yang sangat menunjang dalam dunia pendidikan, penelitian dan pengabdian masyarakat adalah perpustakaan perguruan tinggi.

Menurut Sulisto Basuki (1991:2.172.18) perpustakaan perguruan tinggi adalah perpustakaan yang ada pada perguruan tinggi atau lembaga yang setara dengan perguruan tinggi dimana perpustakaan perguruan tinggi bertujuan untuk membantu mewujudkan Tri Dharma Perguruan Tinggi yaitu Pendidikan, Penelitian dan Pengabdian Masyarakat, yang termasuk perpustakaan perguruan tinggi ialah perpustakaan jurusan, bagian, dapertemen, fakultas, universitas, isntitut, sekolah tinggi, politeknik, akademi maupun perpustakaan program nongelar.

Setiap perpustakaan selalu mengalami pengembangan koleksi entah itu setiap bulan, enam bulan ataupun tahun, tergantung pada kebijakan masingmasing perpustakaan. Pengembangan koleksi bertujuan untuk memenuhi kebutuhan pengguna atau user guna mempermudah pengguna dalam mencari informasi yang dibutuhkan di perpustakaan. Dalam pengembangan koleksi ada beberapa tahapan yang dilakukan. Evans, menggambarkan proses pengembangan koleksi terdiri dari enam komponen kegiatan yaitu analisis masyarakat, kebijakan seleksi, seleksi, pengadaan, penyiangan dan evaluasi (Yulia dan Sujana, 2007:1.9).

Seiring berkembangya zaman dan informasi semakin uptudate, maka perpustakaan harus mengadakan koleksi bahan pustaka, sehingga kebutuhan pengguna akan informasi yang uptudate terpenuhi. Pengadaan bahan pustaka tersebut dilakukan oleh pustakawan, staf 
yang bersangkutan, ada beberapa cara untuk mengadakan bahan pustaka seperti pembelian, hadiah, tukar menukar dan sumbangan.

Perpustakaan jurusan Pendidikan Bahasa Inggris Fakultas Tarbiyah Dan Keguruan Universitas Islam Negeri Antasari Banjarmasin sebagai perpustakaan perguruan tinggi yang bertugas memberikan informasi, melayani, menyediakan bahan pustaka bagi para mahasiswa pendidikan bahasa inggris yang mana informasi informasi yang di butuhkan para mahasiswa tersebut adalah informasi yang berkaitan dengan dunia pendidikan, penelitan, pengabdian masyarakat dalam konteks bahasa inggris. Koleksi yang terdapat dalam perpustakaan tersebut lumayan cukup, masih belum bisa dikatakan banyak karna ada beberapa bahan pustaka yang jumlahnya masih terbatas, dan hampir semua penerbit koleksi bahan pustaka nya berasal dari luar negri.

Jurusan Pendidikan Bahasa Inggris adalah jurusan yang memiliki perpustakaan khusus di Universitas Islam Negeri Antasari Banjarmasin, oleh karnanya dana yang di dapat perpustakaan tentunya sangat tertabas, karna perpustakaan ini di bawah naungan jurusan bukan fakultas. Hal ini menjadi suatu ketertarikan penulis dalam melakukan penelitian di perpustakaan tersebut.

Berdasarkan latar belakang di atas peneliti tertarik menulis tentang Pengadaan Koleksi di Perpustakaan Jurusan Pendidikan Bahasa Inggris Universitas Islam Negeri Antasari Banjarmasin, karena peneliti beranggapan bahwa pengadaan bahan pustaka merupakan salah satu kegiatan penting dalam proses pengembangan koleksi suatu perpustakaan, yang mana salah satu kualitas perpustakaan dapat terlihat dari koleksi koleksi yang dimiliki oleh perpustakaan tersebut. oleh karena itu peneliti ingin mengidentifikasi proses pengadaan yang di lakukan oleh perpustakaan Pendidikan Bahasa Inggris.

\section{KERANGKA TEORITIS}

1. Perpustakaan Perguruan Tinggi

Perpustakaan perguruan tinggi ialah perpustakaan yang terdapat pada perguruan tinggi, badan bawahannya maupun lembaga yang berafiliasi dengan perguruan tinggi, tujuan utamanya yaitu membantu perguruan tunggi mencapai tujuannya. Tujuan perguruan tinggi di indonesia di kenal dengan Tri Dharma perguruan tinggi pendidikan, penelitian dan pengabdian masyarakat, yang termasuk perpustakaan perguruan tinggi 
ialah perpustakaan jurusan, bagian, dapertemen, fakultas, universitas, isntitut, sekolah tinggi, politeknik, akademi maupun perpustakaan program nongelar (Sulisto Basuki 1991:2.17-2.18). Secara umum tujuan perpustakaan perguruan tinggi adalah sebagai berikut.

a. Memenuhi kebutuhan informasi masyarakat perguruan tinggi, seperti staf dan mahasiswa, dan tenaga administrasi perguruan tinggi.

b. Menyediakan materi perpustakaan seperti rujukan atau referensi pada semua tingkat akademis, mulai dari mahasiswa tahun pertama hingga ke mahasiswa program pascasarjana dan dosen d perguruan tinggi tersebut.

c. Menyediakan ruang belajar untuk pemustaka atau user perpustakaan.

d. Menyediakan jasa peminjaman.

e. Menyediakan jasa informasi aktif yang terbatas pada lingkungan perguruan tinggi saja, tetapi juga lembaga industri lokal Sulisto Basuki (1991:2.17-2.19).

2. Pengadaan Bahan Pustaka atau Koleksi

Pengadaan atau acquisition adalah kegiatan yang merupakan implementasi dari keputusan dalam melakukan seleksi yang mencakup semua kegiatan untuk mendapatkan bahan pustaka yang telah dipilih dengan cara membeli, tukar menukar, dan hadiah termasuk dalam menyelesaikan administrasinya (Djamarin, 2015:10).

Menurut Sutarno dalam Rahayu (2017:2) pengadaan bahan pustaka adalah langkah awal dalam mengisi perpustakaan dengan sumber-sumber informasi. Pengadaan acquisition yakni suatu kegiatan mengadakan bahan pustaka yang tercetak maupun tidak tercetak untuk dijadikan koleksi perpustakaan guna memenuhi kebutuhan pemustaka akan informasi juga dapat menjadi daya tarik pemustaka untuk ke perpustakaan. Pengadaan bahan pustaka merupakan bagian kegiatan dari kegiatan pengembangan koleksi. Pengadaan bahan pustaka merupakan kegiatan memilih, menghimpun kemudian dilanjutkan dengan mengadakan bahan pustaka yang sesuai dengan prosedur yang mengatur kegiatan pengadaan bahan pustaka. Prosedur kegiataan pengadaan diatur dalam kebijakan pengembangan koleksi. Pengadaan bahan pustaka dilakukan untuk dapat memenuhi kebutuhan pemustaka atau useer dan untuk menghindari masuknya koleksi yang dinilai kurang berguna bagi pemustaka. Kegiatan pengadaan bahan pustaka di perguruan tinggi melibatkan para pustakawan, dosendosen dan mahasiswa karena pengadaan 
bahan pustaka juga harus menyesuaikan dengan kebutuhan pemustaka yang berada di lingkungan perguruan tinggi tersebut.

\section{Kebijakan Pengadaan Bahan Pustaka atau Koleksi}

Kebijakan yang penting selain kebijakan seleksi dan koleksi adalah kebijakan pengadaan. Kebijakan pengadaan adalah berisi prosedur yang harus di gunakan untuk memperoleh bahan pustaka yang sesuai dengan kebutuhan pemustaka, seperti membuat format pemesanan, daftar agen yang akan di ajak untuk mengadakan berbagai macam bahan pustaka, prosedur yang akan digunakan dalam memperlakukan preformed invoice, dan menentukan bahan pustaka akan di tempatkan dimana, apabila ada beberapa perpustakaan di instansi tersebut misalnya, cara memperoleh bahan pustaka adalah pembelian, pertukaran dan hadiah (Yulia dan Sujana, 2007:2.20).

\section{a. Pembelian}

Pembelian dalam pengadaan bahan pustaka atau koleksi dapat di lakukan melalu toko buku, agen buku, bahkan penerbit lokal maupun penerbit luar negeri, bahkan seiring tekhnologi dan informasi, pemesanan buku dapat di lakukan melaui internet, jadi transaksi pemesanan dan pembelian menjadi lebih mudah. Salah satu tempat membeli buku di internet yang terkenal adalah Amazone.com (Yulia dan Sujana, 2007:2.20).

\section{b. Pertukaran}

Pertukaran dalam pengadaan bahan pustaka atau koleksi dapat di lakukan guna menambah bahan pustaka di suatu perpustakaan. Kegiatan ini dapat di laksanakan apabila perpustakaan tersebut memeliki terbitan sebagai bahan pertukaran. Artinya perpustakaan harus memiliki hasil terbitannya sendiri sehingga dapat melaksanakan kegiatan tukar menukar dengan perpustakaan lain. Dalam pertukaran ini tentunya adanya tahapan kesepakan yang harus di lakukan dengan perpustakaan yang bersangkutan (Yulia dan Sujana, 2007:2.21).

\section{c. Hadiah}

Hadiah dalam pengadaan bahan pustaka atau koleksi tentunya untuk menambah bahan pustaka yang ada di perpustakaan memalui hadiah atau hibah dari donator seperti lembaga, instansi, perusahaan, masyarakat dan sebagainya. Bahan pustaka melaui hadaih bisa di peroleh secara langsung maupun secara permintaan. Hadiah yang di terima atau diminta harus berdasarkan persyarakan yang telah di tetapkan oleh perpustakaan, apakah bidang ilmu yang di terima sesuai 
dengan bidang ilmu yang sedang di kembangkan atau tidak (Yulia dan Sujana, 2007:2.20).

4. Kendala Dalam Pengadaan Bahan Pustaka atau Koleksi.

Dalam melakukan pengadaan bahan pustka atau koleksi memang tidak semudah seperti membeli buku untuk kepentingan pribadi, tentuntunya banyak pertimbangan dan kendala yang di alami ketika proses pengadaan koleksi. Menurut Yulia, beberapa persoalan yang sering di alami oleh pustakan di indonesia dalam pengadaan bahan pustaka di antaranya :

\section{a. Terbitan Dalam Negeri}

Tempat penerbitan yang ada di indonesia berpusat di pulau jawa, khususnya di kota jakarta, bandung, yogyakarta, surabaya dan beberapa kota besar lainnya. Sehingga perpustakaan yang berada di luar pulau jawa seperti pul au kalimantan kesulitan dalam pemesanan buku.

b. Prosedur Pembayaran

Dalam prosedur pembayaran ini tidak jarang terjadi yang namanya terbelit belit atau rumit, baik untuk pembayaran dalam bentuk rupiah maupun dollar atau mata uang asing.

\section{c. Ketersediaan Dana}

Anggaran atau ketersediaan dana menang hal yang sangat utama dalam kendala pengadaan bahan pustaka, tidak semua perputakaan dana yang tersedia selalu tepat waktu. Bagi perpustakaan pemerintah biasanya penyediaan dana kurang lancar, berbeda dengan perpustakaan swasta yang penyediaan dana umumnya terbilang lancar.

\section{d. Katalog Penerbit}

Informasi mengenai buku yang tersedia terbatas untuk terbitan luar negeri, dibandingkan dengan terbitan oleh penerbit swasta yang dapat dibeli di toko buku dan pasaran.

e. Administrasi

Administrasi selalu menjadi hal yang di rumitkan, begitu pula dalam pengadaan bahan pustaka, pengadaan buku yang berasal dari luar negeri harus melalui proses pemeriksaan oleh petugas bae cukai dan instansi yang terkait (Yulia dan Sujana, 2007:5.3-5.4)

\section{METODE PENELITIAN}

Metode penelitian yang di gunakan peneliti dalam penilitian ini adalah metode deskripsi kulaitatif. Menurut Bogdan dan 
Taylor dalam Moleong mengataka bahwa pendekatan kualitatif menghasilkan data deskriptif berupa kata- kata tertulis atau lisan dari orang-orang dan perilaku yang dapat di amati (Muchtar, 2012:70). Teknik dalam pengumpulan data penelitian ini adalah observasi, wawancara dan dokumentasi, sumber data yang di dapat oleh peneliti melalui sumber data primer dan sekundar. Sumber data primer di dapat melalui wawancara sedangkan sumber data sekunder di dapat melalui jurnal, penelitian terdahulu, internet, buku-buku guna mendukung penelitian ini.

\section{PEMBAHASAN}

Berdasarkan hasil observasi, wawancara serta dokumntasi yang di lakukan oleh peneliti di perpustakaan jurusan Pendidikan Bahasa Inggris Fakultas Tarbiyah Dan Keguruan Universitas Islam Negeri Antasari Banjarmasin yang terletak di Jl.A.Yani Km 4,5 Banjarmasin Timur, Kota Banjarmasin Kalimantan Selatan, pada tanggal 18-20 oktober 2017 maka peneliti akan mendeskripsikan hasil penelitian berdasarkan metode kualitatif.

Perpustakaan Jurusan Pendidikan Bahasa Inggris Fakultas Tarbiyah Dan Keguruan Universitas Islam Negeri Antasari Banjarmasin adalah perpustakaan yang dapat dikatakan sebagai mini perpustakaan, pengguna atau user perpustakaan hanya untuk mahasiswa mahasiswi pendidikan bahasa inggris karna koleksi pustaka dan sumber informasi yang ada di dalam perpustakaan tersebut berupa koleksi-koleksi yang menunjang sistem pendidikan, pengajaran, penelitian dan pengabdian masyarat di bidang pendidikan bahasa inggris dan sastra. Pustawakan yang ada di di perustakaan ini berjumlah dua orang, jumlah koleksi semua buku adalah 1.537 di tambah dengan skripsi sekitar 400 an dan CD. Perpustakan ini menyediakan satu komputer atau PC guna mempermudah mahasiswa mengakses e-book daan jurnal yang di butuhan secara online maupun ofline.

Pengadaan bahan pustaka atau koleksi di perpustakaan jurusan pendidikan bahasa inggris fakultas tarbiyah dan keguruan universitas islam negeri antasari ini belum sepenuhnya menerapkan pengadaan bahan pustaka yang berpedoman pada Standard Operating Procedure SOP. Menurut Rahayu, (2017:5) dalam kegiatan pengadaan bahan pustaka atau koleksi yang berpedoman pada Standard Operating Procedure SOP meliputi tiga kegiatan, yang pertama pemilihan atau seleksi bahan pustak, kedua 
alat bantu seleksi bahan pustaka dan yang terakhir pengecekan anggaran dan membuat skala prioritas.

Kegiatan pengadaan bahan pustaka di perpustakaan jurusan pendidikan bahasa inggris tentunya mempunyai anggaran atau dana yang selalu menjadi kompenen penting dalam pengadaan bahan koleksi. Anggaran yang di dapat oleh perpustakaan ini tidak menentu tiap bulan, 3 bulan, 6 bulan bahkan tahun nya, karena perpustakaan ini masih belum mempunyai anggaran tetap. Dana yang di dapatkan memalui mahasiswa, di setiap semester, mahasiswa dan mahasiswa lama maupun baru di wajibkan membayar 15 ribu untuk perpustakaan, kemudian anggaran tetap dari fakultas untuk perpustukaan masih terbilang belum ada anggaran yang spesifik, karna jurusan pendidikan bahasa inggris adalah jurusan yang satu satunya mempunyai perpustakaan sendiri, jadi apabila jurusan menerima dana dari fakultas, jurusan akan menyisihkan seperempat dana tersebut untuk perpustkaan. Kebijakan ini di tentuntkan oleh ketua jurusan dan pustakawan di perpustakaan tersebut.

Prosedur pemilihan atau seleksi bahan pustaka di perpustakaan ini di tentukan oleh dosen-dosen pendidikan bahasa inggris, staf-staf, pustawakan dan juga melibatkan mahasiswa. Mahasiswa yang terlibat dalam kegiatan ini adalah anggota Himpunan Mahasiswa Jurusan (HMJ), akan tetapi mahasiswa yang bukan dari anggota HMJ tetap berpartisipasi dengan cara memberikan saran secara tertulis di kotak saran yang ada di perpustakaan. Mereka memilih dan menyeleksi bahan pustaka apa saja yang sesuai dengan kebutuhan mahasiswa. Misalnya informasi tentang Linguistic, English for Young Learner, English for Spesific Porpuses masih belum banyak terdapat di perpustakaan, sehingga mahasiswa yang berminat penelitian di bidang tersebut kekurangan dalam bahan pustaka, jadi pihak-pihak yang terkait akan menentukan bahwa bahan pustaka yang masih kurang dan di butukan itulah yang akan di adakan atau dibeli.

Adapun dalam sistem pengadaan bahan pustaka di perpustakann jurusan melalui, pembelian, hadiah dan sumbangan.

\section{a. Pembelian}

Pembelian bahan pustaka dilakukan tidak melalui online ataupun bertarget setiap bulan atau tahun. Pembelian di lakukan secara langsung mebeli ke toko buku atau penerbit yang bersangkutan, dalam satu atau dua bulan dosen-dosen akan betugas ke luar kota seperti pulau 
jawa bahkan tidak jarang para dosen bertugas ke luar negri, dalam kesempatan itulah para dosen akan membeli bahan pustaka yang dibutuhkan oleh perpustakaan.

b. Hadiah

Pihak yang biasanya memberikan hadiah kepada perpustakaan jurusan adalah Regional English Language Office (RELO) kedutaan besar dan konsultan AS di indonesia. Pihak RELO memberikan bahan pustaka yang berkaitan dengan pengajaran bahasa inggris.

c. Sumbangan

Sumbangan yang di dapat oleh perpustakaan adalah dari mahasiswa pendidikan bahasa inggris. Para mahasiswa yang sudah menyelesaikan sidang munaqosah atau ujian skripsi mereka wajib untuk menyumbang satu bahan pustaka untuk perpustkaan jurusan, buku yang akan di sumbangkan sesuai dengan bahan pustaka yang dibutuhkan di perpustakaan tersebut, tentunya mereka akan berkonsultasi terlebih dahulu dengan pihak yang terkait bahan pustaka apa saja yang masih belum terpenuhi guna memenuhi informasi yang dibutuhkan para mahasiswa.
Kendala dalam pengadaan bahan koleksi tentunya selalu menjadi permasalahan, kendala yang terdapat di perpustakaan jurusan dalam pengadaan bahan koleksi adalah anggaran yang terbilang tidak menetap dan masih kurang. Penerbit atau toko buku yang menyediakan bahan pustaka yang perlukan oleh jurusan terbilang sulit untuk di dapat meskipun $\mathrm{d}$ pulau jawa, karna buku-buku yang ada di perpustakaan jurusan rata-rata terbitan luar negeri sehingga koleksi di perpustakaan tersebut lumayan terbatas. Dengan keterbatasan koleksi maka kebijakan peminjaman hanya berlaku untuk dua hari dan apabila terlamat maka mahasiswa membayar denda.

\section{KESIMPULAN}

Berdasarkan penelitian tentang Pengadaan Bahan Pustaka atau Koleksi di Perpustakaan Jurusan Pendidikan Bahasa Inggris Fakultas Tarbiyah dan Keguruan Universitas Islam Negeri Antasai Banjarmasin, penulis dapat mengambil kesimpulan bahwa perpustakaan jurusan adalah perpustakaan yang khusus untuk mahasiswa pendidikan bahasa inggris, jumlah pustawakannya adah dua orang dan sistem pengadaan koleksi belum berpedoman dengan SOP. Anggaran yang terdapat di perpustakaan ini tidak mempunyai anggaran yang menetap di 
setiap bulan atau pertahunnya. Prosedur pemilihan bahan koleksi di tentukan oleh para dosen, staf, pustakan dan mahaisswa. Sistem pengadaan bahan koleksi melaui pembelian, hadiah dan sumbangan.

\section{SARAN}

Pengadaan bahan pustaka Pengadaan Bahan Pustaka atau Koleksi di Perpustakaan Jurusan Pendidikan Bahasa Inggris Fakultas Tarbiyah dan Keguruan Universitas Islam Negeri Antasai Banjarmasin hendaknya menambah tenaga pustakawan dalam mengelola perpustakaan dan sebaiknya tenaga tersebut berasal dari background pendidikan DIII atau S1 prpustakaan sehingga pengadaan bahkan pengembahan koleksi di perpustakaan dapat berjalan sesuai dengan semestinya.

Dana yang tersedia dalam
pengadaan koleksi terbilang tidak
menentu, oleh karna itu hendaknya pihak
jurusan dan perpustakaan meminta
anggaran tetap kepada pihak yang
bersangkutan guna terjalinnya kegiatan
pengadaan koleksi yang teratur.

\section{DAFTAR PUSTAKA}

Basuki, Sulistyo. (1991). Pengantar Ilmu Perpustakaan. Jakarta: Gramedia Pustaka Utama.

Djamarin, Maulida. (2015). Pengadaan Koleksi E-Journal dan Buku Pada Perpustakaan UNP Dana BO-PTN. Padang: Universitas Negeri Padang .

Evans, G. Edward, and Margaret R. Zarnosky. (2000). Developing Library and Information Center Collection. Colorado: Libraries Unlimited. Englewood.

Handayani, Mutia. (2013). Pengembangan koleksi perpustakaan E-Journal. Padang: Stain Padangsimpuan

Muchtar, Rusdi. (2012). Penelitian Kulitatif dan Kuantitatif Serta Praktek Kombinasinya dalam Penelitian sosial. Yogyakarta:Publica Institute.

Rahayu, Ni Putu Dewi Gardina. (2017). Pengadaan Bahan Pustaka Di Perpustakaan Pusat Universitas Warmadewa E-journal. Bali : Universitas Udayana.

Ratnaningsih. (2017). Pengadaan Bahan Pustaka Di Perguruan Tinggi : Suatu Pengalaman Di Perpustakaan Institut Pertanian Bogor E-Journal. Bogor: Institut Pertanian Bogor.

Yulia, Yutu dan Sujana G. Janti. (2007). Pengembangan koleksi. jakarta:Universitas Terbuka. 